\title{
Plasma leptin concentrations in postmenopausal women with osteoporosis
}

\author{
Ersin Odabaşı ${ }^{1}$, Metin Ozata ${ }^{2}$, Mustafa Turan ${ }^{1}$, Necati Bingöl ${ }^{3}$, Arif Yönem ${ }^{2}$, Bekir Çakır ${ }^{2}$, Mustafa Kutlu ${ }^{2}$ \\ and İ Çağlayan Özdemir ${ }^{2}$ \\ Departments of ${ }^{1}$ Hydroclimatology and ${ }^{2}$ Endocrinology and Metabolism, Gülhane School of Medicine, Etlik, Ankara, Turkey and ${ }^{3}$ Bayındır Medical \\ Center, Söğütözü-Ankara, Turkey \\ (Correspondence should be addressed to M Ozata, Associate Professor of Medicine, Department of Endocrinology and Metabolism, \\ Gülhane School of Medicine, Etlik-Ankara, Turkey 06018; Email: mozata@obs.gata.edu.tr)
}

\begin{abstract}
Background: The obese are usually protected against osteoporosis and have increased bone mineral density and plasma leptin concentrations. A recent in vitro study demonstrated that leptin acts on human marrow stromal cells to enhance differentiation to osteoblasts, suggesting an influence of leptin on bone mass. However, little is known about the relationship between plasma leptin and bone mass in postmenopausal women with osteoporosis.

Objective: To investigate plasma leptin concentrations in postmenopausal women with osteoporosis to improve the understanding of the role of leptin in determining bone mass.

Methods: Fifty postmenopausal women with osteoporosis (ages $61.18 \pm 6.51$ years; body mass index (BMI) $28.91 \pm 3.44 \mathrm{~kg} / \mathrm{m}^{2}$, mean \pm S.D.) and 30 age- and BMI-matched healthy postmenopausal women were included in the study. Bone mineral densities (BMD) were measured by dual energy X-ray absorptiometry. Plasma leptin concentrations were determined using an immunoradiometric assay. Results: The median spine BMD value in the patient group $\left(0.695 \pm 8.26 \mathrm{~g} / \mathrm{cm}^{2}\right.$, median \pm S.E.M. $)$ was significantly lower than that in the control group $\left(1.006 \pm 1.29 \mathrm{~g} / \mathrm{cm}^{2}\right.$, median \pm S.E.M.; $z=-7.454$, $P<0.001)$. The median plasma leptin concentration in the patient group $(18.70 \pm 1.78 \mathrm{ng} / \mathrm{ml}$, median \pm s.E.M. $)$ was not significantly different from that in the control group $(22.35 \pm 2.20 \mathrm{ng} / \mathrm{ml}$, median \pm S.E.M.; $z=-1.630, P=0.103)$. Plasma leptin concentrations were correlated with $\mathrm{BMI}$ in both groups $\left(r_{\mathrm{s}}=0.394, P=0.031\right.$ in controls and $r_{\mathrm{s}}=0.404, P=0.004$ in the patient group). There was no correlation between plasma leptin concentrations and BMD values in controls $\left(r_{\mathrm{s}}=-0.107\right.$, $P=0.575)$ but a weak correlation was observed in the patient group $\left(r_{\mathrm{s}}=0.285, P=0.045\right)$. Conclusion: Our data suggest that circulating plasma leptin does not have a significant direct influence on bone mass in postmenopausal women.
\end{abstract}

European Journal of Endocrinology 142 170-173

\section{Introduction}

Leptin, the hormonal product of the $O B$ gene, plays an important part in the regulation of food intake, energy expenditure, and body weight (1). The leptin gene is expressed in adipose tissue, gastric epithelium and placenta (2-4). Plasma leptin concentrations correlate with body fat content; they are increased in obesity and decreased in anorexia nervosa $(4,5)$. Moreover, it has recently been shown that, in addition to its effects on food intake and energy expenditure, leptin influences the secretion of follicle-stimulating hormone, luteinizing hormone, adrenocorticotropic hormone, cortisol and growth hormone (6-9).

The obese are usually protected against osteoporosis and have increased bone mineral density (10). This has been attributed to the mechanical effects of their excessive weight on bone tissue. Obese postmenopausal women have a tendency to have increased bone mineral density compared with lean women (11-13). A recent in vitro study demonstrated that leptin acts on human marrow stromal cells to enhance differentiation to osteoblasts, suggesting a role of leptin in bone metabolism (14). These findings have prompted speculations on the possible role of leptin in the protective effect of obesity on bone. Moreover, there are few reports on the relationship between bone mineral density and plasma leptin concentrations; in those studies, no significant relationship between circulating plasma leptin and bone mass was reported $(15,16)$. To understand further the influence of leptin on bone mass, we have investigated the relationship between plasma leptin and bone mineral density in postmenopausal women with osteoporosis. 


\section{Patients and methods}

Fifty postmenopausal women with osteoporosis (ages (mean \pm s.D.) $61.18 \pm 6.51$ years, range $50-76$ years; body mass index (BMI) (mean \pm S.D.) $28.91 \pm 3.44 \mathrm{~kg} /$ $\mathrm{m}^{2}$, range $21.87-37.19 \mathrm{~kg} / \mathrm{m}^{2}$ ) and 30 age- and BMImatched healthy postmenopausal women (ages (mean \pm s.D.) $58.30 \pm 6.02$ years, range 50-71 years; BMI (mean \pm S.D.) $29.46 \pm 2.79 \mathrm{~kg} / \mathrm{m}^{2}$, range $25.64-$ $36.25 \mathrm{~kg} / \mathrm{m}^{2}$ ) were included in the study.

Patients who had vertebral fractures, surgical menopause, secondary osteoporosis or other medical conditions that may affect the skeleton or metabolism were excluded from the study. Patients treated previously with bisphosphonates, calcitonin, anabolic steroids or hormone replacement therapy at any time since menopause were also excluded. Patients with vertebral fractures were excluded from the study, to achieve homogeneity.

The diagnosis of osteoporosis was based on spine bone mineral density (BMD) measurements. Patients with spine BMD 2.5 standard deviations below a reference range established using our own data obtained from a Turkish population of normal healthy women using dual energy X-ray absorptiometry ( $T$ score less than -2.5) were accepted as having osteoporosis. BMI was defined as weight in kilograms divided by (height in meters $)^{2}$. BMD $\left(\mathrm{g} / \mathrm{cm}^{2}\right)$ was determined at the level of the second to fourth lumbar vertebrae (spine) by dual energy X-ray absorptiometry (Norland XR 36-WBL, Fort Atkinson, WI, USA). Plasma leptin concentrations were determined by using an immunoradiometric assay (Active Human Leptin IRMA, DSL-23100, Diagnostic System Laboratories Inc., Webster, TX, USA).

After overnight fasting, blood samples were collected in ethylenediamine tetra-acetate-coated venepuncture tubes. All samples were promptly centrifuged, separated and stored at $-70{ }^{\circ} \mathrm{C}$ until required for the leptin assay. All plasma samples were run in the same assay.

All participants gave their informed consent to take part in the study, which was approved by the local ethics committee of Gülhane School of Medicine.

\section{Statistical analysis}

The data for time since menopause, leptin, and BMD measurements were not distributed normally, therefore the Mann-Whitney U-test was used for comparisons. The data for age, and BMI were distributed normally, and an unpaired $t$-test was used for comparisons. Spearman correlations were used to explore correlations between the variables. All statistical calculations were performed using a Windows-compatible statistical package. $P$ values less than 0.05 were accepted as significant. Values are given as median \pm S.E.M. for nonnormally distributed data and as mean \pm S.D. for normally distributed data.

\section{Results}

Clinical and laboratory data are given in Table 1. Time since menopause was not significantly different between the two groups ((median \pm s.E.M.) $14.00 \pm 1.01$ years, range 3-29 years for patients and $12.00 \pm 1.43$ years, range 2-27 years for controls; $z=-0.607, P=0.544$ ). Plasma leptin concentration in the patient group was not significantly different from that in the control group $(18.70 \pm 1.78 \mathrm{ng} / \mathrm{ml}$ and $22.35 \pm 2.20 \mathrm{ng} / \mathrm{ml}$, respectively; $z=-1.630, P=0.103)$. Plasma leptin concentrations were correlated with BMI in both control and patient groups $\left(r_{\mathrm{s}}=0.394, P=0.031\right.$ and $r_{\mathrm{s}}=0.404$, $P=0.004$, respectively; Fig. 1). No correlation was observed between plasma leptin and BMD in controls, but there was a weak correlation in the patient group $\left(r_{\mathrm{s}}=-0.107, P=0.575\right.$ and $r_{\mathrm{s}}=0.285, P=0.045$, respectively).

\section{Discussion}

The main finding of this study was that there was no significant difference in plasma leptin concentrations between patient and control groups. Plasma leptin concentrations were not correlated with bone mass in the control group. Although a correlation between plasma leptin concentration and bone mass was observed in the patient group, the strength of this relationship $\left(r_{\mathrm{s}}^{2}=0.081\right)$ was weak, in that only $8 \%$ of the variance in the BMD measurements could be accounted for by the leptin concentration. These findings suggest that circulating plasma leptin does not have a direct influence on bone mass in postmenopausal women.

Table 1 Clinical and laboratory characteristics of the patient and control groups. Values are median \pm S.D. (†) or S.E.M

\begin{tabular}{lccr}
\hline & Patients $(n=30)$ & Controls $(n=50)$ & \multicolumn{1}{c}{$\boldsymbol{P}$} \\
\hline Age (years) $\dagger$ & $61.18 \pm 6.51$ & $58.30 \pm 6.02$ & $0.053 \ddagger$ \\
BMI $\left(\mathrm{kg} / \mathrm{m}^{2}\right) \dagger$ & $28.91 \pm 3.44$ & $29.46 \pm 2.79$ & $0.466 \ddagger$ \\
$\mathrm{BMD}\left(\mathrm{g} / \mathrm{cm}^{2}\right)$ & $0.695 \pm 0.01$ & $1.006 \pm 0.01$ & $<0.001 \S$ \\
Leptin $(\mathrm{ng} / \mathrm{ml})$ & $18.70 \pm 1.78$ & $22.35 \pm 2.20$ & $0.103 \S$ \\
Time since menopause (years) & $14.00 \pm 1.013$ & $12.00 \pm 1.43$ & $0.544 \S$ \\
\hline
\end{tabular}

‡Unpaired $t$-test; §Mann-Whitney $U$ test. 


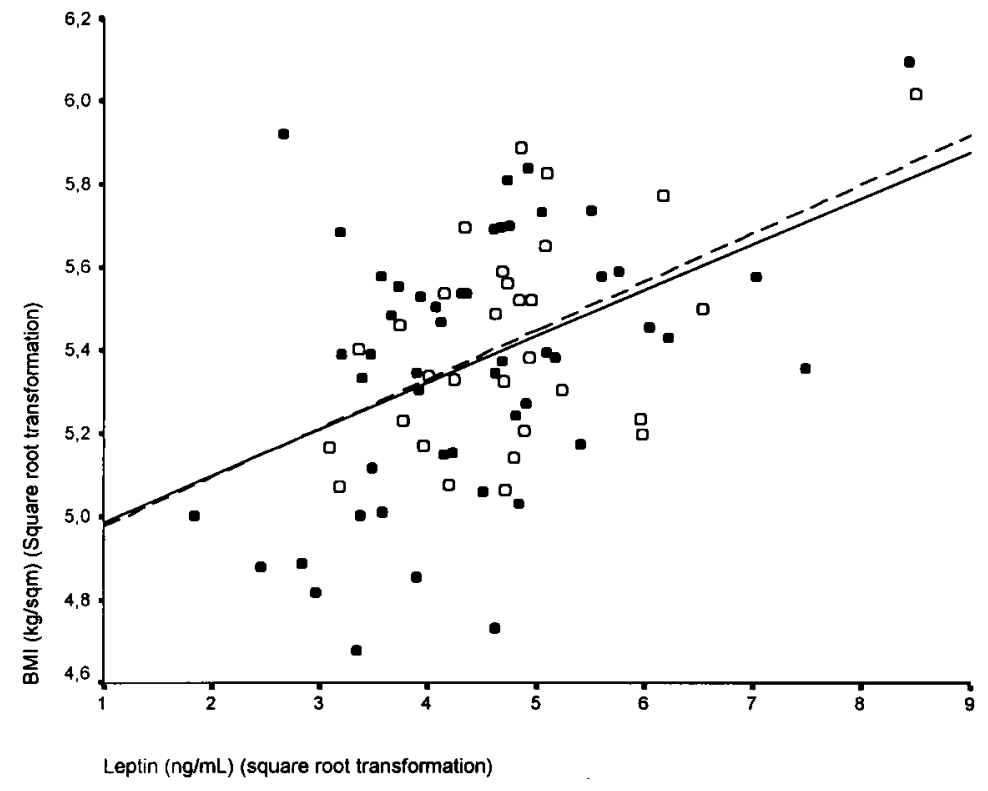

Figure 1 Correlation between $\mathrm{BMI}$ and plasma leptin concentration in patients with osteoporosis $\left(r_{\mathrm{s}}=0.404, P=0.004\right)$ and in normal individuals $\left(r_{\mathrm{s}}=0.394, P=0.031\right) . Y=0.1115 x+4.8757$ for patients $(-)$ and $Y=0.1178 x+4.8585$ for controls (- - ). ๑, patients; $\bigcirc$, controls.
There are many reports indicating that osteoporosis and particularly hip fractures are less frequent in obese subjects (10-13). Obese and overweight women have a greater bone mass after menopause than lean women of the same age $(10,13)$. This protective effect appears to be related to both a high fat content and mechanical factors (13). Some studies suggest that greater concentrations of estrogen, decreased sex hormone binding globulin and increased free sex steroids, insulin-like growth factor-I and hyperinsulinemia are responsible for greater bone mass in obese women $(10,13)$. It is also interesting to note that both bone mass and plasma leptin concentrations are increased in obesity. A recent study indicates that leptin acts on human marrow stromal cells to enhance differentiation to osteoblasts, suggesting a role of leptin on bone metabolism (14). We have recently demonstrated that a genetically leptindeficient obese patient had osteopenia, in spite of morbid obesity $(17,18)$. These findings suggest that leptin may have a role in bone and mineral metabolism.

There are few reports on the relationship between bone mineral density and plasma leptin concentrations. Klein et al. (19) reported that obese children were younger, taller, and had more advanced bone maturation than non-obese children of similar pubertal stage. However, they found similar BMD values in obese and non-obese children. Goulding \& Taylor (15) did not find any relationship between BMD and plasma leptin concentrations in postmenopausal women, but they found a positive relationship between fat mass and bone mass. Similarly, Rauch et al. (16) also failed to find a relation between circulating plasma leptin and bone mass in adult women. In agreement with the findings of previous studies, we were unable to find a strong relationship between plasma leptin concentration and BMD in postmenopausal women with osteoporosis.
Plasma leptin concentrations were not significantly different between our patients with osteoporosis and the controls. Our data suggest that circulating plasma leptin concentrations may not act directly on bone in postmenopausal women.

Conversely, it is known that adipocytes participate in the microenvironment of the bone marrow and that these adipocytes are a secondary source of leptin production (20). Thomas et al. (14) recently demonstrated a direct osteogenic effect of leptin on a human marrow stromal cell line with the capability to differentiate to either osteoblasts or adipocytes. Thus it is possible that local production of leptin may play a part in bone metabolism.

Although effects of local leptin production in the bone microenvironment cannot be excluded, our data suggest that circulating plasma leptin does not have a significant direct influence on bone mass in postmenopausal women.

\section{Acknowledgements}

We are grateful to Turkish Merck Sharp \& Dohme Inc. for their kind support in providing leptin IRMA kits.

\section{References}

1 Zhang Y, Proenca R, Maffei M, Barone M, Leopold L \& Friedman JM. Positional cloning of the mouse obese gene and its human homologue. Nature $1994372425-432$.

2 Bado A, Levasseur S, Attoub S, Kermorgant S, Laigneau JP, Bortoluzzi MN et al. The stomach is a source of leptin. Nature $1998394790-793$.

3 Masuzaki H, Ogawa Y, Sagawa N, Hosoda K, Matsumoto T, Mise H et al. Nonadipose tissue production of leptin: leptin as a novel placenta-derived hormone in humans. Nature Medicine 19973 1029-1033. 
4 Considine RV, Sinha MK, Heiman ML, Kriauciunas A, Stephens TW, Nyce MR et al. Serum immunoreactive-leptin concentrations in normal-weight and obese humans. New England Journal of Medicine 1995334 292-295.

5 Grinspoon S, Gulick T, Askari H, Landt M, Lee K, Anderson E et al. Serum leptin levels in women with anorexia nervosa. Journal of Clinical Endocrinology and Metabolism 199681 3861-3863.

6 Ahima RS, Prabakaran D, Mantzoros C, Ou D, Lowell B, MaratosFlier E et al. Role of leptin in the neuroendocrine response to fasting. Nature 1996382 250-252.

7 Barash IA, Cheung CC, Weigle DS, Ren H, Emilia BK \& Kuijper JL. Leptin is a metabolic signal to the reproductive system. Endocrinology $19961373144-3147$.

8 Licinio J, Negrão AB, Mantzoros CS, Kaklamani V, Wong ML, Bongiorno PB et al. Synchronicity of frequently sampled, 24-h concentrations of circulating leptin, luteinizing hormone and estradiol in healthy women. Proceedings of the National Academy of Sciences of the USA 199895 2541-2546.

9 Licinio J, Mantzoros C, Negrao AB, Cizza G, Wong ML, Bongiorno $\mathrm{PB}$ et al. Human leptin levels are pulsatile and inversely related to pituitary-adrenal function. Nature Medicine 19983 575-579.

10 Albala C, Yanez M, Deveto E, Sostin C, Zeballos L \& Santos Jl. Obesity as a protective factor for postmenopausal osteoporosis. International Journal of Obesity and Related Metabolic Disorders $1996201027-1032$.

11 Riggs BL \& Melton J. Involutional osteoporosis. New England Journal of Medicine 1986314 676-685.

12 Dequeker J \& Boonen S. Osteoporosis in clinical practice. In Extraskeletal Risk and Protective Factors for Fractures, pp 55-58. Ed P Geuseus. London: Springer, 1998.

13 Ribot C, Tremollieres F, Pouilles JM, Bonneu M, Germain F \& Louvet JP. Obesity and postmenopausal bone loss: the influence of obesity on vertebral density and bone turnover in postmenopausal women. Bone $19878327-331$.
14 Thomas T, Gori F, Khosla S, Jensen MD, Burguera B \& Riggs Bl. Leptin acts on human marrow stromal cells to enhance differentiation to osteoblasts and to inhibit differentiation to adipocytes. Endocrinology 1999140 1630-1638.

15 Goulding A \& Taylor RW. Plasma leptin values in relation to bone mass and density dynamic biochemical markers of bone resorption and formation in postmenopausal women. Calcified Tissue International 199863 456-458.

16 Rauch F, Blum WF, Klein K, Allolio B \& Schonau E. Does leptin have an effect on bone in adult women? Calcified Tissue International 199863 453-455.

17 Strobel A, Issad T, Camoin L, Ozata M \& Strosberg AD. A leptin missense mutation associated with hypogonadism and morbid obesity. Nature Genetics 199818 213-215.

18 Ozata M, Ozdemir IC \& Licinio J. Human leptin deficiency caused by a missense mutation: Multiple endocrine defects, decreased sympathetic tone, and immune system dysfunction indicate new targets for leptin action, greater central than peripheral resistance to the effects of leptin, and spontaneous correction of leptinmediated defects. Journal of Clinical Endocrinology and Metabolism 199984 3686-3695.

19 Klein KO, Kimberly AL, Elizabeth L, Brown JM, Considine R \& Hassink SG. Effect of obesity on estradiol level, and its relationship to leptin, bone maturation, and bone mineral density in children. Journal of Clinical Endocrinology and Metabolism 199883 34693475 .

20 Laharrague P, Larrouy D, Fontanilles AM, Truel N, Campfield A, Tenenbaum $\mathrm{R}$ et al. High expression of leptin by human bone marrow adipocytes in primary culture. FASEB Journal 199812 747-752.

Received 27 May 1999

Accepted 21 October 1999 